\title{
Analisis kesesuaian vegetasi di Lapangan Puputan Badung I Gusti Ngurah Made Agung, Denpasar, Bali
}

\author{
I Gusti Ayu Tria Nareswari ${ }^{1 \star}$, I Gusti Alit Gunadi², I Gusti Agung Ayu Rai Asmiwyati ${ }^{1}$ \\ 1. Prodi Arsitektur Pertamanan, Fakultas Pertanian, Universitas Udayana, Jl. P.B. Sudirman, \\ Denpasar, Indonesia \\ 2. Prodi Agroekoteknologi, Fakultas Pertanian, Universitas Udayana, Jl. P.B. Sudirman, Denpasar, \\ Indonesia \\ *E-mail: nareswaritria@gmail.com
}

\begin{abstract}
Analyze of Vegetation Suitability at Lapangan Puputan Badung I Gusti Ngurah Made Agung, Denpasar, Bali. Lapangan Puputan Badung I Gusti Ngurah Made is a city park in Denpasar that has various functions including as a producer of oxygen, public recreation space for urban communities, and city aesthetics. This study aims to analyze the suitability of vegetation type for city park and analyze the effect of vegetation placement on garden user activities. The method used is observation to obtain data about the type of vegetation and user activities in several areas of the park. The literature study method is used to develop vegetation suitability indicators for city parks and assess the suitability of each vegetation. The results obtained are 64 types of vegetation which are composed of groundcovers, shrubs, and trees. Based on research, as many as 53 types of vegetation are suitable and 11 other types are quite suitable for city parks. The vegetation functions as shade, limiting view, and aesthetics. This function affects user activity in several areas in the park, which limits the view of road users to the park or otherwise, providing a comfortable resting place and facilities throughout the day.
\end{abstract}

Keywords: Lapangan Puputan Badung, suitability analyze, vegetation.

\section{Pendahuluan}

Ruang terbuka hijau (RTH) menjadi ruang yang penting untuk dimiliki setiap wilayah perkotaan. Kota Denpasar memiliki berbagai bentuk RTH kota salah satu diantaranya adalah Lapangan Puputan Badung I Gusti Ngurah Made Agung yang berupa taman kota. Fungsi ekologis taman kota mampu menyediakan ruang resapan air, oksigen, hingga kenyamanan. Fungsi lainnya seperti fungsi sosial budaya dan estetika mampu memberikan ruang bagi masyarakat untuk bersosialisasi dan berekreasi serta mememperindah kota.

Elemen pembentuk taman kota didominasi oleh vegetasi dengan persentase sebanyak $80 \%-90 \%$ (DPU, 2008). Vegetasi adalah komponen pembentuk lanskap taman kota yang harus diperhatikan, tidak hanya karena komponen penting tetapi vegetasi adalah komponen lanskap yang terus tumbuh dan berkembang. Setiap vegetasi juga memiliki karakteristik yang berbeda. Karakteristik inilah yang harus diperhatikan dalam perencanaan penanaman. Pemahaman mengenai karakteristik vegetasi dapat membantu dalam pemilihan vegetasi, penentuan fungsi dalam lanskap serta peletakkannya. Kesalahan dalam pengaplikasian vegetasi di taman kota dapat membatasi ruang gerak pengguna taman, membahayakan pengunjung, menghambat pertumbuhan tanaman serta mengurangi keindahan taman kota. Oleh karena itu, perlu dilakukan analisis kesesuaian vegetasi di Lapangan Puputan Badung I Gusti Ngurah Made Agung berdasarkan karakteristik vegetasi serta menganalisis pengaruh peletakkan vegetasi terhadap aktivitas pengguna pada ruang tertentu di taman kota.

\section{Metode Penelitian}

Penelitian dilakukan di Lapangan Puputan Badung I Gusti Ngurah Made Agung yang berlokasi di pusat (0 km) Kota Denpasar (Gambar 1) dengan elevasi 26 mdpl. Penelitian ini dimulai dari Mei 2018 hingga November 2018. Alat yang digunakan kalkulator, kamera digital, Microsoft Word, Microsoft Exel, AutoCAD, dan Adobe Photoshop. Bahan yang digunakan adalah desain Lapangan Puputan Badung I Gusti Ngurah Made Agung melalui citra satelit Google Earth Pro. 


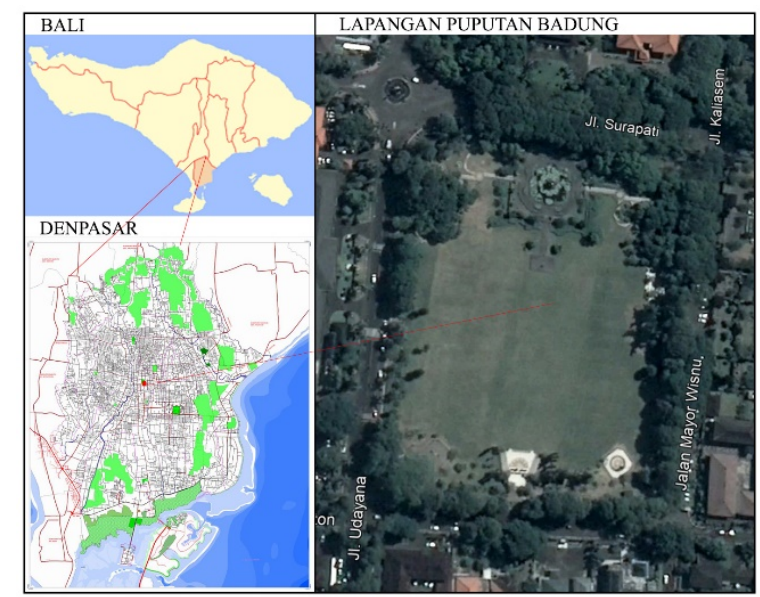

Gambar 1. Lokasi Penelitian (Google.com dan Google Map, 2018)

Metode pengumpulan data yang digunakan dalam penelitian ini berupa metode observasi dan metode studi pustaka. Metode observasi digunakan untuk mengumpulkan data mengenai kondisi eksisting serta aspek biofisik taman. Metode studi pustaka digunakan dalam penentuan indikator kesesuaian vegetasi dan penilaian setiap vegetasi.

\subsection{Metode Penelitian}

Metode penelitian yang dilakukan untuk mencapai tujuan penelitian dilakukan dalam beberapa tahapan antara lain:

\subsubsection{Inventariasi}

Tahapan inventarisasi dilakukan dengan melihat kondisi eksisting taman dilihat dari aspek biofisik untuk memperoleh informasi yang berkaitan dengan kondisi tapak untuk penanaman vegetasi. Aspek biofisik tersebut meliputi lokasi dan batas tapak, tanah, hidrologi, iklim, vegetasi serta fasilitas.

\subsubsection{Analisis}

Analisis data yang dilakukan dalam penelitian ini adalah analisis untuk mengetahui karakteristik setiap jenis vegetasi yang ada di taman. Analisis tersebut meliputi analisis kesesuaian vegetasi berdasarkan karakteristik vegetasi yang sesuai ditanam pada taman kota serta pengamatan peletakan vegetasi pada tapak.

1. Analisis Kesesuaian Vegetasi untuk Taman Kota

Analisis kesesuaian vegetasi dilakukan terhadap seluruh strata vegetasi dalam taman. Analisis kesesuaian vegetasi secara spesifik untuk fungsi taman kota dilakukan dengan memberikan skor terhadap setiap jenis vegetasi berdasarkan karakteristik dan habitus tanaman tersebut jika tumbuh secara ideal. Indikator kesesuaian yang digunakan dalam penelitian ini dibagi berdasarkan habitus vegetasi yakni penutup tanah, semak, dan pohon. Indikator kesesuaian vegetasi dapat dilihat pada Tabel 1.

Tabel 1. Indikator Kesesuaian Vegetasi

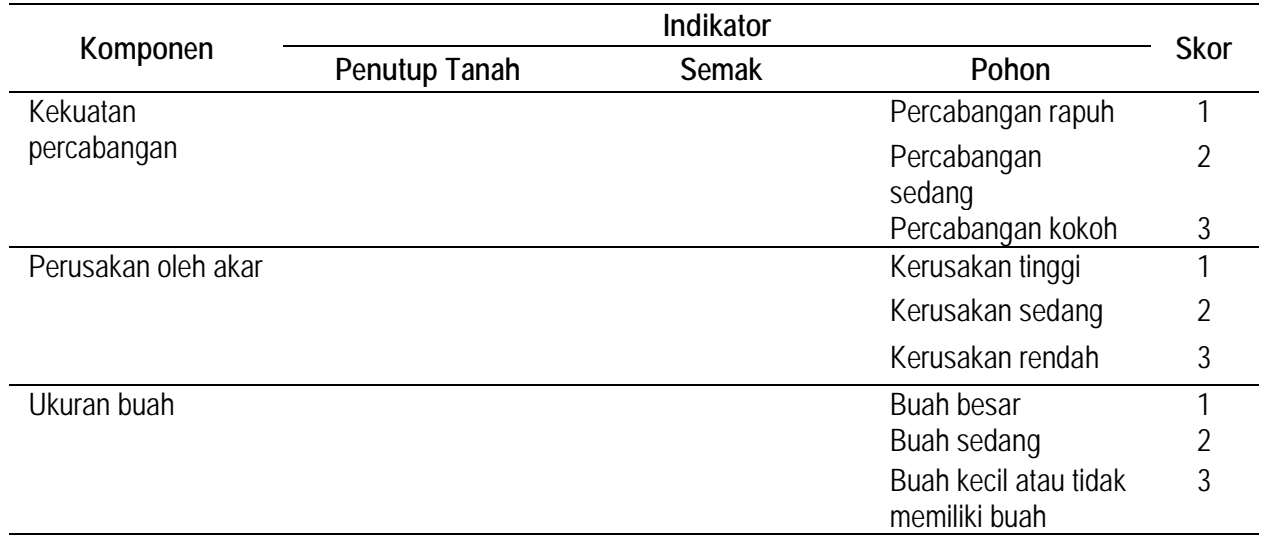




\begin{tabular}{|c|c|c|c|c|}
\hline \multirow{2}{*}{ Komponen } & \multicolumn{3}{|c|}{ Indikator } & \multirow{2}{*}{ Sko } \\
\hline & Penutup Tanah & Semak & Pohon & \\
\hline \multirow[t]{2}{*}{$\begin{array}{l}\text { Bagian tanaman } \\
\text { beracun }\end{array}$} & $\begin{array}{l}\text { Memiliki bagian } \\
\text { tanaman yang } \\
\text { beracun }\end{array}$ & $\begin{array}{l}\text { Memiliki bagian } \\
\text { tanaman yang } \\
\text { beracun }\end{array}$ & $\begin{array}{l}\text { Memiliki bagian } \\
\text { tanaman yang } \\
\text { beracun }\end{array}$ & 1 \\
\hline & $\begin{array}{l}\text { Tidak memiliki bagian } \\
\text { tanaman yang } \\
\text { beracun }\end{array}$ & $\begin{array}{l}\text { Tidak memiliki bagian } \\
\text { tanaman yang } \\
\text { beracun }\end{array}$ & $\begin{array}{l}\text { Tidak memiliki bagian } \\
\text { tanaman yang } \\
\text { beracun }\end{array}$ & 2 \\
\hline \multirow[t]{2}{*}{ Duri } & Memiliki duri & Memiliki duri & Memiliki duri & 1 \\
\hline & Tidak memiliki duri & Tidak memiliki duri & Tidak memiliki duri & 2 \\
\hline $\begin{array}{l}\text { Sifat menggugurkan } \\
\text { daun }\end{array}$ & & $\begin{array}{l}\text { Menggugurkan daun } \\
\text { Evergreen }\end{array}$ & $\begin{array}{l}\text { Menggugurkan daun } \\
\text { Evergreen }\end{array}$ & $\begin{array}{l}1 \\
2\end{array}$ \\
\hline \multirow[t]{3}{*}{ Sinar matahari } & $\begin{array}{l}\text { Kebutuhan cahaya } \\
\text { sedikit atau perlu } \\
\text { naungan }\end{array}$ & $\begin{array}{l}\text { Kebutuhan cahaya } \\
\text { sedikit atau perlu } \\
\text { naungan }\end{array}$ & $\begin{array}{l}\text { Kebutuhan cahaya } \\
\text { sedikit atau perlu } \\
\text { naungan }\end{array}$ & 1 \\
\hline & $\begin{array}{l}\text { Kebutuhan cahaya } \\
\text { sedang atau sedikit } \\
\text { ada naungan }\end{array}$ & $\begin{array}{l}\text { Kebutuhan cahaya } \\
\text { sedang atau sedikit } \\
\text { ada naungan }\end{array}$ & $\begin{array}{l}\text { Kebutuhan cahaya } \\
\text { sedang atau sedikit } \\
\text { ada naungan }\end{array}$ & 2 \\
\hline & $\begin{array}{l}\text { Kebutuhan cahaya } \\
\text { penuh atau langsung }\end{array}$ & $\begin{array}{l}\text { Kebutuhan cahaya } \\
\text { penuh atau langsung }\end{array}$ & $\begin{array}{l}\text { Kebutuhan cahaya } \\
\text { penuh atau langsung }\end{array}$ & 3 \\
\hline \multirow[t]{3}{*}{ Kebutuhan air } & Kebutuhan air banyak & Kebutuhan air banyak & Kebutuhan air banyak & 1 \\
\hline & Kebutuhan air sedang & Kebutuhan air sedang & Kebutuhan air sedang & 2 \\
\hline & Kebutuhan air sedikit & Kebutuhan air sedikit & Kebutuhan air sedikit & 3 \\
\hline \multirow[t]{3}{*}{$\begin{array}{l}\text { Tajuk, percabangan, } \\
\text { daun, dan/atau } \\
\text { bunga }\end{array}$} & $\begin{array}{l}\text { Penampilan bentuk } \\
\text { dan warna tidak } \\
\text { menarik }\end{array}$ & $\begin{array}{l}\text { Penampilan bentuk } \\
\text { dan warna tidak } \\
\text { menarik }\end{array}$ & $\begin{array}{l}\text { Penampilan bentuk } \\
\text { dan warna tidak } \\
\text { menarik }\end{array}$ & 1 \\
\hline & $\begin{array}{l}\text { Penampilan bentuk } \\
\text { dan warna cukup } \\
\text { menarik }\end{array}$ & $\begin{array}{l}\text { Penampilan bentuk } \\
\text { dan warna cukup } \\
\text { menarik }\end{array}$ & $\begin{array}{l}\text { Penampilan bentuk } \\
\text { dan warna cukup } \\
\text { menarik }\end{array}$ & 2 \\
\hline & $\begin{array}{l}\text { Penampilan bentuk } \\
\text { dan warna menarik }\end{array}$ & $\begin{array}{l}\text { Penampilan bentuk } \\
\text { dan warna menarik }\end{array}$ & $\begin{array}{l}\text { Penampilan bentuk } \\
\text { dan warna menarik }\end{array}$ & 3 \\
\hline \multirow[t]{2}{*}{$\begin{array}{l}\text { Menarik kupu-kupu } \\
\text { atau burung }\end{array}$} & & $\begin{array}{l}\text { Tidak menarik kupu- } \\
\text { kupu atau burung }\end{array}$ & $\begin{array}{l}\text { Tidak menarik kupu- } \\
\text { kupu atau burung }\end{array}$ & 1 \\
\hline & & $\begin{array}{l}\text { Menarik kupu-kupu } \\
\text { atau burung }\end{array}$ & $\begin{array}{l}\text { Menarik kupu-kupu } \\
\text { atau burung }\end{array}$ & 2 \\
\hline
\end{tabular}

Sumber: Mukhlison (2013) dan DPU (2008) dengan modifikasi

Penentuan kesesuaian setiap strata vegetasi dilakukan dengan menjumlahkan seluruh skor setiap jenis vegetasi yang diperoleh dari hasil survei lapangan dan tinjauan pustaka. Setelah itu, setiap jenis vegetasi dikelompokkan menjadi tiga kelas kriteria kesesuaian yaitu tidak sesuai, cukup sesuai, dan sesuai. Interval skor setiap kelas didapat melalui rumus berikut:

$$
R=\frac{N_{m a k s}-N_{\min }}{3}
$$

Keterangan:

$\begin{array}{ll}\mathrm{R} & =\text { Interval kelas } \\ \mathrm{N}_{\text {maks }} & \text { = Jumlah skor maksimal setiap strata vegetasi } \\ \mathrm{N}_{\min } & \text { = Jumlah skor minimum setiap strata vegetasi }\end{array}$

Adapun rentangan kelas nilai kesesuaian dapat dilihat pada Tabel 2.

Tabel 2. Rentangan Nilai Kesesuaian Vegetasi

\begin{tabular}{|c|c|c|c|c|c|c|c|}
\hline \multirow{2}{*}{ No. } & \multirow{2}{*}{ Vegetasi } & \multirow{2}{*}{$\begin{array}{l}\text { Jumlah } \\
\text { Indikator }\end{array}$} & \multirow{2}{*}{ Nmaks } & \multirow{2}{*}{$\mathrm{N}_{\min }$} & \multicolumn{3}{|c|}{ Rentangan Nilai } \\
\hline & & & & & KS & CS & S \\
\hline 1. & Penutup Tanah & 5 & 13 & 5 & $5-7,7$ & $>7,7-10,4$ & $>10,4-13$ \\
\hline 2. & Semak & 7 & 17 & 7 & $7-10,3$ & $>10,3-13,7$ & $>13,7-17$ \\
\hline 3. & Pohon & 10 & 26 & 10 & $10-15,3$ & $>15,3-20,7$ & $>20,7-26$ \\
\hline & yan: $\begin{aligned} \text { TS } & =\text { Tic } \\
\text { CS } & =\mathrm{Cu} \\
\mathrm{S} & =\mathrm{Se}\end{aligned}$ & $\begin{array}{l}\text { up Sesuai } \\
\text { uai Sesuai }\end{array}$ & & & & & \\
\hline
\end{tabular}




\section{Analisis Peletakkan Vegetasi}

Analisis peletakkan vegetasi dilakukan secara deskriptif dari hasil observasi untuk melihat pengaruh peletakkan suatu vegetasi terhadap tapak tersebut. Hal yang diperhatikan berupa fungsi vegetasi dan pengaruhnya terhadap aktivitas pada tapak tersebut. Beberapa tempat yang dianalisis pada tapak ini terbagi atas tujuh area yaitu jalur joging, area monumen, area bermain anak, area gym, panggung, area terapi dan area duduk serta lapangan. Adapun ciri-ciri fungsi arsitektural yang diamati menurut Departemen Pekerjaan Umum tahun 2008 dan 2012 dapat dilihat pada Tabel 3.

Tabel 3. Ciri-Ciri Fungsi Arsitektural Vegetasi

\begin{tabular}{ll}
\hline Fungsi & Ciri-Ciri \\
\hline Pembatas & Vegetasi pohon, perdu atau semak \\
Pandang & Massa daun padat \\
& Jarak tanam rapat dan kontinu \\
\hline Pengarah & Vegetasi pohon, perdu atau semak \\
& Ditaman berbaris dan kontinu \\
\hline Peneduh & Pohon dengan tinggi $7 \mathrm{~m}-15 \mathrm{~m}$ \\
& Bentuk tajuk menyebar, bulat, dome atau tak beraturan \\
& Massa daun padat atau ditanam secara berbaris dan tajuk \\
& bersinggungan \\
\hline Estetika & Bentuk atau warna tajuk, percabangan, daun, bunga \\
& bervariasi \\
\hline
\end{tabular}

Sumber: DPU 2008 dan DPU 2012

\section{Hasil dan Pembahasan}

\subsection{Gambaran Umum Lapangan Puputan Badung I Gusti Ngurah Made Agung}

Lapangan Puputan Badung I Gusti Ngurah Made Agung memiliki luas 33.810 m2. Lapangan Puputan Badung I Gusti Ngurah Made Agung terletak di Kecamatan Denpasar Barat, Kelurahan Dauh Puri Kangin dengan elevasi 26 mdpl. Suhu rata-rata di Lapangan Puputan Badung I Gusti Ngurah Made Agung selama lima tahun terakhir adalah $27,8^{\circ} \mathrm{C}$ (BMKG, 2018).

Lapangan Puputan Badung I Gusti Ngurah Made Agung memiliki elemen pembentuk lanskap berupa softscape (vegetasi) dan hardscape (elemen keras). Elemen keras pada tapak ini berupa Monumen Puputan Badung, planterbox, tiang bendera, kolam, pompa air, tiang listrik, pengeras suara, papan informasi, pos polisi, tempat sampah, dan tempat penyimpanan barang-barang pemeliharaan taman. Elemen keras lainnya berupa fasilitas pendukung aktivitas meliputi jalur joging, area terapi, area bermain anak, area gym, area merokok, panggung, gazebo, toilet, bangku dan meja taman dan lampu taman.

Lapangan Puputan Badung I Gusti Ngurah Made Agung memiliki aksesibilitas yang mudah. Lapangan ini dapat diakses oleh kendaraan bermotor roda dua maupun roda empat. Terdapat empat ruas jalan yang dapat dituju untuk mencapai lapangan ini yaitu Jalan Mayor Wisnu, Jalan Sugianyar, Jalan Udayana, dan Jalan Surapati.

\subsection{Nilai Kesesuaian Vegetasi di Lapangan Puputan Badung I Gusti Ngurah Made Agung}

Hasil inventarisasi yang dilakukan menghasilkan data vegetasi sebanyak 64 jenis. Keseluruhan spesies tersebut terdiri atas delapan jenis penutup tanah, 31 jenis semak, dan 25 jenis pohon. Setiap jenis dinilai berdasarkan indikator untuk menentukan nilai serta tingkat kesesuaian vegetasi tersebut.

Vegetasi berupa penutup tanah di Lapangan Puputan Badung I Gusti Ngurah Made Agung didominasi oleh rumput-rumputan. Penggunaan penutup tanah banyak ditemukan pada lapangan dan sisanya tersebar di sekitar jalur joging. Nilai kesesuaian vegetasi penutup tanah disajikan pada Tabel 4 .

Secara umum pemilihan vegetasi penutup tanah memang sudah memenuhi nilai kesesuaian jika dilihat dari keseluruh aspek sehingga nilai yang dihasilkan tinggi. Akan tetapi, beberapa jenis vegetasi memiliki kekurangan karena berbahaya. Jenis vegetasi tersebut diantaranya Adam Hawa (T. spathacea), Wedelia (S. trilobata), dan Bromelia (A. fulgens dan B. pyramidalis). Penggunaan Adam Hawa (T. spathacea) dan Wedelia (S. trilobata) sebagai penutup tanah dapat digunakan tetapi tidak dianjurkan karena vegetasi ini beracun jika termakan oleh manusia. Selain itu, Bromelia juga cukup berbahaya karena memiliki duri pada bagian daunnya 
(National Parks Singapore, 2013). Penggunaan Adam Hawa, Wedelia, dan Bromelia pada sebuah taman dapat disiasati dengan menjauhkan penanaman vegetasi tersebut dari daerah yang dekat dengan aktivitas manusia.

Tabel 4. Nilai Kesesuaian Vegetasi Penutup Tanah

\begin{tabular}{cllcc}
\hline No. & \multicolumn{1}{c}{ Nama IImiah } & \multicolumn{1}{c}{ Nama Umum } & $\begin{array}{c}\text { Nilai } \\
\text { Kesesuaian }\end{array}$ & Keterangan \\
\hline 1. & Tradescantia spathacea & Adam Hawa & 11 & $\mathrm{~S}$ \\
2. & Aechmea fulgens & Bromelia & 10 & $\mathrm{CS}$ \\
3. & Billbergia pyramidalis & Bromelia & 10 & $\mathrm{CS}$ \\
4. & Ruellia simplex & Ruelia & 12 & $\mathrm{~S}$ \\
5. & Eleusine indica & Rumput Belulang & 10 & $\mathrm{CS}$ \\
6. & Axonopus compressus & Rumput Paetan & 10 & $\mathrm{CS}$ \\
7. & Cuphea hyssopifolia & Taiwan Beauty & 12 & $\mathrm{~S}$ \\
8. & Sphagneticola trilobata & Wedelia & 10 & $\mathrm{CS}$ \\
\hline
\end{tabular}

Sumber: Analisis Data

Keterangan: $\quad S=$ Sesuai

CS = Cukup Sesuai

Strata vegetasi selanjutnya yaitu semak. Semak yang digunakan di Lapangan Puputan Badung I Gusti Ngurah Made Agung terdiri atas 31 jenis. Keseluruhan jenis ini banyak ditemukan pada area Monumen Puputan Badung dan planterbox sekitar jalur joging. Berdasarkan observasi, Teh-tehan (Acalypha siemensis) adalah semak yang paling banyak digunakan di Lapangan Puputan Badung I Gusti Ngurah Made Agung. Penanaman semak di tapak ini banyak ditanam secara bergerombol dan beberapa lainnya ditanam secara individu. Hasil penilaian kesesuaian vegetasi semak untuk ditanam di Lapangan Puputan Badung I Gusti Ngurah Made Agung dapat dilihat pada Tabel 5.

Semak di Lapangan Puputan Badung I Gusti Ngurah Made Agung banyak difungsikan sebagai komponen estetika dan pembatas. Semak yang dipilih merupakan vegetasi dengan nilai estetika yang baik. Nilai estetika tersebut didapat dari bentuk maupun warna bagian tanaman seperti percabangan, daun, dan bunga. Oleh sebab itu banyak nilai keindahan vegetasi mendapatkan nilai yang tinggi. Beberapa contoh vegetasi dengan daya tarik berupa percabangan yaitu Lee Kwan Yu ( $V$. elliptica) dan Kaktus ( $C$. hildmannianus). Vegetasi dengan daya tarik daun dan bunga dapat diliat pada Agave ( $F$. foetida), Andong (C. Fruticosa), Puring (C. variegatum), Lidah Mertua (S. trifasciata), Philodendron ( $P$. xanadu), Bugenvil (Baugainvillea sp.), Pisang Hias ( $H$. densiflora), Kembang Sepatu (H. rosa-sinensis), dan Melati Jepang ( $P$. carruthersii). Nilai terendah diperoleh Teh-tehan karena kurangnya daya tarik dari vegetasi ini. Teh-tehan dapat menjadi menarik jika dilakukan perawatan seperti topiari. Teh-tehan memiliki kelebihan yaitu pertumbuhan percabangan maupun daun yang rapat sehingga tanaman ini efektif jika digunakan sebagai pembatas untuk mengatur sirkulasi, meredam kebisingan maupun membatasi pemandangan yang tidak ingin dilihat.

Indikator lainnya yang berpengaruh dalam penilaian nilai kesesuaian vegetasi semak adalah penarik kupu-kupu atau burung. Min et al. (2014) menyebutkan daftar vegetasi yang dapat menarik kupu-kupu atau burung. Berdasarkan daftar tersebut semak di Lapangan Puputan Badung I Gusti Ngurah Made Agung yang dapat menarik kupu-kupu atau burung diantaranya adalah Kembang Sepatu (H. rosa-sinensis), Melati Jepang (P. carruthersii), Pangkas Kuning (D. erecta), Pisang Hias (H. densiflora), dan Soka (I. javanica).

Beberapa semak di Lapangan Puputan Badung I Gusti Ngurah Made Agung belum memenuhi persyaratan keamanan baik dari segi kandungan racun ataupun duri. Menurut data National Parks Singapore (2013) vegetasi seperti Puring (C. variegatum), Patah Tulang (P. tithymaloides), dan Pangkas Kuning ( $D$. erecta) dapat menyebabkan iritasi dan keracunan jika terkena maupun tertelan bagian tanaman tertentu. Vegetasi lainnya cukup berbahaya karena berduri seperti Agave ( $F$. foetida), Bugenvil (Bougainvillea sp.), Kaktus (C. hildmannianus), Pangkas Kuning (D. erecta), dan Sikas (C. revoluta). 
Tabel 5. Nilai Kesesuaian Vegetasi Semak

\begin{tabular}{|c|c|c|c|c|}
\hline No. & Nama Latin & Nama Umum & $\begin{array}{c}\text { Nilai } \\
\text { Kesesuaian }\end{array}$ & Keterangan \\
\hline 1. & Furcraea foetida & Agave & 14 & S \\
\hline 2. & Cordyline fruticosa & Andong & 15 & $S$ \\
\hline 3. & Neomarica longifolia & Anggrek Tanah & 14 & $S$ \\
\hline 4. & Osmoxylon lineare & Aralia & 15 & $S$ \\
\hline 5. & Bougainvillea 'Singapore White' & Bugenvil & 15 & S \\
\hline 6. & Bougainvillea 'Singapore Pink' & Bugenvil & 15 & S \\
\hline 7. & Acalypha wilkesiana & Copper Leaf & 14 & $S$ \\
\hline 8. & Ophiopogon jaburan & Jaburan & 14 & $\mathrm{~S}$ \\
\hline 9. & Gardenia jasminoides & Jempiring & 14 & S \\
\hline 10. & Asplenium nidus & Kadaka & 15 & $S$ \\
\hline 11. & Cereus hildmannianus & Kaktus & 14 & S \\
\hline 12. & Hibiscus rosa-sinensis & Kembang Sepatu & 16 & S \\
\hline 13. & Tabernaemontana divaricata & Korimbosa & 15 & S \\
\hline 14. & Vernonia elliptica & Lee Kwan Yu & 15 & $S$ \\
\hline 15. & Sansevieria trifasciata & Lidah Mertua & 15 & $S$ \\
\hline 16. & Pseuderanthemum carruthersii & Melati Jepang & 15 & $\mathrm{~S}$ \\
\hline 17. & Platycerium bifurcatum & Paku Tanduk Rusa & 14 & $\mathrm{~S}$ \\
\hline 18. & Duranta erecta & Pangkas Kuning & 13 & CS \\
\hline 19. & Pedilanthus tithymaloides & Patah Tulang & 14 & $\mathrm{~S}$ \\
\hline 20. & Philodendron xanadu & Philodendron & 14 & $\mathrm{~S}$ \\
\hline 21. & Heliconia densiflora & Pisang Hias & 14 & S \\
\hline 22. & Plumbago auriculata & Plumbago & 15 & S \\
\hline 23. & Codiaeum variegatum & Puring & 14 & $S$ \\
\hline 24. & Aerva sanguinolenta & Sambang Colok & 15 & $\mathrm{~S}$ \\
\hline 25. & Excoecaria cochinchinensis & Sambang Darah & 15 & S \\
\hline 26. & Cycas revoluta & Sikas & 15 & $S$ \\
\hline 27. & Ixora javanica & Soka & 16 & $\mathrm{~S}$ \\
\hline 28. & Hymenocallis speciosa & Spider Lily & 14 & $\mathrm{~S}$ \\
\hline 29. & Acalypha siamensis & Teh-tehan & 13 & CS \\
\hline 30. & Nymphaea cultivar & Tunjung & 14 & $\mathrm{~S}$ \\
\hline 31. & Dracaena fragrans & Sari Gading & 14 & $S$ \\
\hline
\end{tabular}

Sumber: Analisis Data

$$
\text { Keterangan: } \quad \begin{array}{ll}
\mathrm{S} & =\text { Sesuai } \\
\mathrm{CS} & =\text { Cukup Sesuai }
\end{array}
$$

Lapangan Puputan Badung I Gusti Ngurah Made Agung memiliki 25 jenis pohon. Pohon banyak ditemukan di sepanjang jalur joging dan sisanya tersebar di pinggir lapangan. Pohon yang ada di tapak ini memiliki habitus yang bervariasi terdiri atas pohon kecil, sedang, besar, bambu, dan beberapa jenis palempaleman. Nilai kesesuaian pohon dapat disajikan pada Tabel 6 .

Secara umum, pohon di tapak ini memperoleh nilai baik pada persyaratan tumbuh karena dapat tumbuh dengan penyinaran matahari langsung dan tidak memerlukan air dalam jumlah besar. Selain persyaratan tumbuh, karakteristik lain yang perlu diperhatikan dalam pemilihan pohon untuk taman kota yaitu sifat menggugurkan daun dan tingkat perusakan oleh akar. Beberapa pohon dari daftar di atas merupakan vegetasi yang menggugurkan daun contohnya Kamboja (P. rubra), Bungur (L. speciosa), Glodokan Tiang ( $P$. longifolia), Ketapang (T. catappa), dan Tabebuya Pink (T. rosea) sedangkan tingkat perusakan oleh vegetasi memiliki rentangan nilai perusakan yang rendah hingga sedang. Pohon dengan tingkat perusakan oleh akar sedang diantaranya Beringin ( $F$. benjamina), Bodhi ( $F$. religiosa) serta palmae seperti Palem Raja ( $R$. regia), dan Pinang (A. catechu) (Urban Forest Ecosystems Institute, 2018).

Hasil keseluruhan penilaian pohon adalah baik akan tetapi beberapa jenis pohon memiliki kekurangan pada indikator tertentu salah satunya keamanan. Indikator pemilihan pohon yang menyangkut keamanan meliputi kekuatan percabangan, ukuran buah, bagian tanaman yang beracun dan duri. Pohon dengan percabangan yang kokoh diantaranya Jatimas (C. sebestena), Tanjung (M. elengi), Bungur (L. 
speciosa), dan Ketapang ( $T$. catappa) sedangkan percabangan yang tidak kokoh dimiliki oleh pohon Kembang Merak (C. pulcherrima), Kamboja (P. rubra), Angsana (P. indicus), dan Bodhi (F. religiosa). Ukuran buah yang besar dapat membahayakan pengguna ataupun menyebabkan kerusakan pada taman oleh sebab itu pemilihan vegetasi dengan buah yang besar lebih baik dihindarkan terutama pada area-area taman yang tergolong aktif salah satunya pohon Maja (C. cujete). Ukuran buah Maja mencapai diameter $25 \mathrm{~cm}$ (Badan Perbenihan Tanaman Hutan Sulawesi, 2012). Pohon dengan bagian tanaman yang berbahaya seperti berduri dan beracun juga tidak banyak ditemukan di Lapangan Puputan Badung I Gusti Ngurah Made Agung. Getah Kamboja dapat menyebabkan iritasi dan daging buah Maja beracun jika dimakan (National Parks Singapore, 2013). Duri hanya ditemukan pada pohon Kembang Merak (C. pulcherrima).

Vegetasi di taman kota tidak hanya mampu menarik kupu-kupu. Pohon di sebuah taman kota juga diharapkan mampu menjadi habitat satwa khususnya burung. Pohon tidak hanya digunakan sebagai tempat tinggal bagi burung tetapi juga menyediakan makan. Beberapa pohon di tapak ini yang menarik burung diantaranya Beringin (F. benjamina), Bodhi (F. religiosa), Glodokan Tiang (P. Iongifolia), dan Palem Raja ( $R$. regia) (Min et al., 2014).

Tabel 6. Nilai Kesesuaian Vegetasi Pohon

\begin{tabular}{|c|c|c|c|c|}
\hline No. & Nama Latin & Nama Umum & $\begin{array}{c}\text { Nilai } \\
\text { Kesesuaian }\end{array}$ & Keterangan \\
\hline \multicolumn{5}{|c|}{ Pohon Kecil (lebar tajuk < $3 \mathrm{~m}$ ) } \\
\hline 1. & Caesalpinia pulcherrima & Kembang Merak & 22 & $S$ \\
\hline \multicolumn{5}{|c|}{ Pohon Sedang (lebar tajuk $3 \mathrm{~m}-8 \mathrm{~m}$ ) } \\
\hline 2. & Michelia alba & Cempaka & 24 & $\mathrm{~S}$ \\
\hline 3. & Cordia sebestena & Jatimas & 25 & $\mathrm{~S}$ \\
\hline 4. & Plumeria rubra & Kamboja & 19 & CS \\
\hline 5. & Crescentia cujete & Maja & 21 & $\mathrm{~S}$ \\
\hline 6. & Syzygium myrtifolium & Pucuk Merah & 24 & $\mathrm{~S}$ \\
\hline 7. & Tabebuia aurea & Tabebuya Kuning & 24 & $\mathrm{~S}$ \\
\hline 8. & Mimusops elengi & Tanjung & 22 & $\mathrm{~S}$ \\
\hline \multicolumn{5}{|c|}{ Pohon Besar (lebar tajuk > $8 \mathrm{~m}$ ) } \\
\hline 9. & Pterocarpus indicus & Angsana & 23 & $\mathrm{~S}$ \\
\hline 10. & Ficus benjamina & Beringin & 22 & $\mathrm{~S}$ \\
\hline 11. & Ficus religiosa & Bodhi & 20 & CS \\
\hline 12. & Lagerstroemia speciosa & Bungur & 23 & $\mathrm{~S}$ \\
\hline 13. & Juniperus chinensis & Cemara Cina & 24 & $\mathrm{~S}$ \\
\hline 14. & Araucaria heterophylla & Cemara Norfolk & 22 & $\mathrm{~S}$ \\
\hline 15. & Polyalthia longifolia & Glodokan Tiang & 22 & $\mathrm{~S}$ \\
\hline 16. & Filicium decipiens & Kiara Payung & 20 & CS \\
\hline 17. & Crateva religiosa & Tigaron & 22 & $\mathrm{~S}$ \\
\hline 18. & Terminalia catappa & Ketapang & 23 & $\mathrm{~S}$ \\
\hline 19. & Tabebuia rosea & Tabebuya Pink & 20 & CS \\
\hline \multicolumn{5}{|c|}{ Bambu } \\
\hline 20. & Pseudosasa japonica & Bambu Jepang & 24 & $S$ \\
\hline \multicolumn{5}{|c|}{ Palmae } \\
\hline 21. & Ptychosperma macarthurii & Palem Hijau & 23 & $\mathrm{~S}$ \\
\hline 22. & Licuala grandis & Palem Kol & 23 & $\mathrm{~S}$ \\
\hline 23. & Dypsis lutescens & Palem Kuning & 24 & $\mathrm{~S}$ \\
\hline 24. & Roystonea regia & Palem Raja & 23 & $\mathrm{~S}$ \\
\hline 25. & Areca catechu & Pinang & 22 & $\mathrm{~S}$ \\
\hline
\end{tabular}

Sumber: Analisis Data

Keterangan: $\quad S=$ Sesuai

CS = Cukup Sesuai 


\subsection{Peletakkan Vegetasi di Lapangan Puputan Badung I Gusti Ngurah Made Agung}

Penyebaran vegetasi secara umum di Lapangan Puputan Badung I Gusti Ngurah Made Agung dapat dilihat pada Gambar 2.

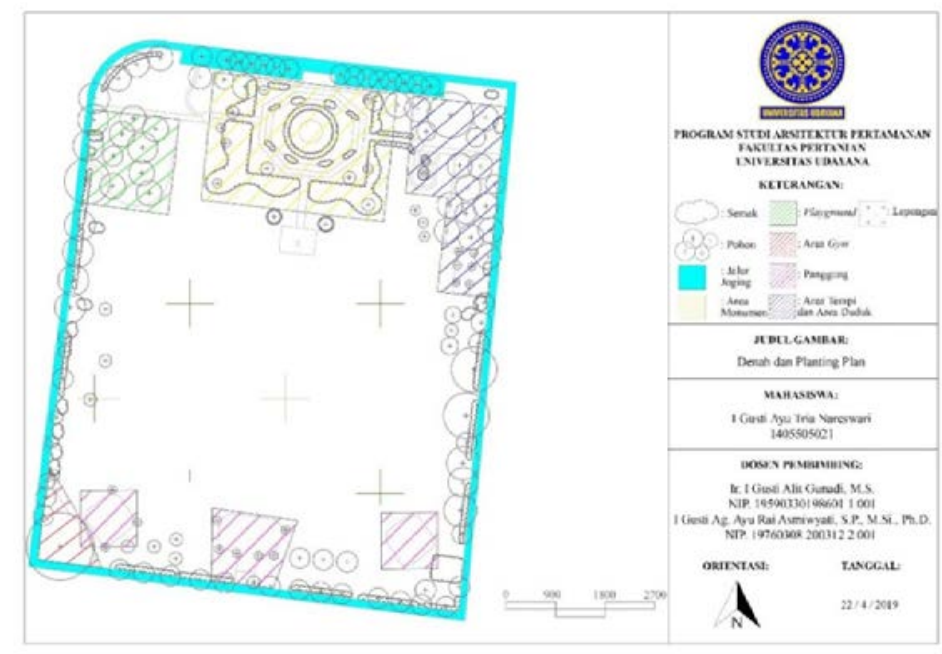

Gambar 2. Denah dan Planting Plan Lapangan Puputan Badung I Gusti Ngurah Made Agung Sumber: Data Penelitian Diolah, 2019

\subsubsection{Jalur Joging}

Lapangan Puputan Badung memiliki jalur joging yang mengitari lapangan ini. Aktivitas utama di jalur joging ini adalah berlari dan berjalan. Selain berlari dan berjalan, aktivitas lain yang ditemukan adalah permainan sepatu roda dan skateboard. Area ini dibentuk oleh 25 jenis vegetasi.

Beberapa pohon bertajuk lebar seperti Bungur, Angsana, dan Bodhi berfungsi sebagai peneduh. Ukuran tajuk yang lebar dan jarak tanam yang rapat menyebabkan jalur joging merupakan daerah yang selalu ternaungi sehingga berbagai kegiatan yang dilakukan di jalur joging dapat dilakukan dengan nyaman. Dominasi Bungur pada area ini tidak hanya digunakan sebagai peneduh tetapi juga pengarah dan estetika terutama saat bunga Bungur sedang mekar. Akan tetapi, mekarnya bunga Bungur ini akan menghasilkan banyak sampah karena jumlahnya yang banyak dan berukuran kecil. Permasalahan lainnya yang timbul karena letak Bungur dan pohon lainnya berada dekat dengan jalur joging yaitu perakaran pepohonan ini merusak perkerasan disekitarnya baik jalur joging maupun planterbox serta percabangan pohon yang melintang di atas jalur joging (Gambar 3) sehingga mengganggu pengguna terutama pengguna jalur khusus difabel. Penanganan yang dapat dilakukan oleh pemerintah yaitu dengan pemindahan pohon maupun penebangan. Selanjutnya hal ini harus menjadi perhatian perancang taman kota maupun pemerintah untuk dapat menyediakan fasilitas yang fungsional.

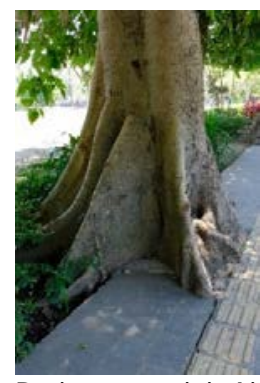

a). Kerusakan Perkerasan oleh Akar Pohon

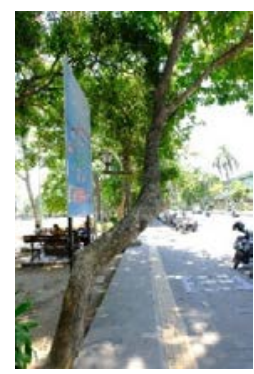

b). Percabangan Menghalangi Jalur Joging

Gambar 3. Dampak Negatif Peletakkan Pohon di Sepanjang Jalur Joging (Dokumentasi, 2018)

Semak pada planterbox ditanam secara berkelompok dan didominasi oleh Teh-tehan serta Melati Jepang, Soka, dan Sari Gading dibeberapa sisi. Semak ditanam secara rapat dengan tinggi berkisar $50 \mathrm{~cm}$ $100 \mathrm{~cm}$. Hal ini dapat membatasi pengguna untuk membuat sirkulasi baru untuk masuk ke dalam lapangan. 
Semak lainnya dengan bentuk, daun, dan warna yang menarik digunakan sebagai estetika seperti Andong, Puring, Pangkas Kuning, dan Sari Gading.

\subsubsection{Area Monumen}

Area ini merupakan area terbuka yang didominasi oleh semak dengan beberapa pohon. Dominasi vegetasi semak pada area ini bertujuan agar Monumen Puputan Badung dapat dilihat tanpa terhalangi. Area monumen memiliki batasan berupa pagar yang terbuat dari beton serta planter box yang mengelilingi area ini.

Pada bagian dalam area monumen beragam jenis semak digunakan terutama semak dengan bunga menarik dan massa daun yang cukup padat seperti Teh-tehan, Soka, Korimbosa, Pangkas Kuning, Spider Lily, dan Plumbago. Selain itu, terdapat beberapa vegetasi yang ditanam dalam pot juga. Vegetasi yang dipilih merupakan vegetasi dengan warna dan bentuk menarik diantaranya Philodendron, Bugenvil, Adam Hawa dan Agave. Agave dan Bugenvil adalah vegetasi berduri yang tidak dianjurkan dalam sebuah taman kota. Pengunaan vegetasi ini dapat mengganggu pengguna taman akan tetapi pada area ini Agave dan Bugenvil ditempatkan pada pedestal dengan tinggi mencapai 1,2 m sehingga kemungkinan pengguna secara tidak sengaja terluka karena duri dari tanaman tersebut sangat kecil.

Pohon yang ditanam di area cenderung ditanam pada bagian pojok seperti Kamboja, Cemara Cina, Tigaron serta vegetasi tinggi seperti Cempaka berada di planterbox bagian luar agar monumen tidak terhalangi. Hal ini menyebabkan tidak adanya tempat berteduh di area ini.

\subsubsection{Area Bermain Anak}

Batasan area ini cukup jelas karena dibatasi oleh planterbox, pedestrian menuju monumen, dan kanstin setinggi $20 \mathrm{~cm}$. Vegetasi yang dominan di area ini adalah Kiara Payung. Kiara Payung dengan massa daun yang padat digunakan sebagai peneduh area ini. Berdasarkan pengamatan, Kiara Payung ditanam cukup rapat di area ini sehingga dapat menutupi keseluruhan area bermain anak. Hal ini menyebabkan area bermain anak selalu ramai digunakan bahkan saat siang hari.

Area ini dibatasi dengan kanstin dan planterbox yang ditanami Cemara Cina dengan ketinggian sekitar 1,2 $\mathrm{m}$ di sebelah timur dan Sari gading, Puring, serta Teh-tehan di sebelah barat yang berbatasan dengan jalur joging. Pembatasan ini mampu mencegah anak-anak untuk bermain terlalu jauh dan memudahkan orang tua untuk mengawasi.

\subsubsection{Area Gym}

Area ini didominasi oleh elemen keras berupa bangku taman, tempat duduk berbahan beton, dan alat olahraga berbahan besi. Jumlah vegetasi yang ditemukan pada area gym sangat sedikit hanya terdapat satu pohon Beringin, satu pohon Kamboja, sekelompok Soka, dan Ruelia.

Beringin memiliki peranan besar di area ini. Beringin termasuk pohon besar dengan ketinggian mencapai $30 \mathrm{~m}$ dan lebar tajuk mencapai $20 \mathrm{~m}$ (Urban Forest Ecosystems Institute, 2018). Hanya dengan kanopi dari satu pohon Beringin area ini dapat tertutupi dengan baik dan area ini menjadi teduh. Pengguna tidak hanya melakukan aktivitas olahraga tetapi pada siang hari banyak orang yang bersantai di area ini. Beringin juga menjadi pusat dari area ini karena letaknya berada di tengah dan ukurannya yang besar. Area ini memiliki batas tidak hanya berupa perkerasan tetapi juga vegetasi yaitu Soka. Soka ditanam sejajar dengan tempat duduk untuk membatasi area gym dengan jalur joging. Selain Soka, Teh-tehan yang ditanam sepanjang jalur joging juga berfungsi membatasi jalur joging dengan area ini sehingga area gym hanya dapat diakses melalui bagian dalam lapangan.

\subsubsection{Panggung}

Fungsi panggung sebagai tempat pertunjukkan atau pementasan mengharuskan tidak adanya halangan bagi penonton untuk melihat ke arah panggung. Oleh karena itu vegetasi yang dipilih adalah vegetasi yang tidak memiliki tajuk lebar hingga menutupi panggung dan peletakkan yang cukup jauh dari panggung. Panggung utama memiliki beberapa vegetasi ditanam secara dekat diantaranya Glodokan Tiang, Kamboja, dan Kembang Merak sedangkan pada panggung lainnya hanya terdapat sedikit pohon Kamboja di dekat panggung. Ketiga vegetasi tersebut juga memiliki nilai estetika yang baik karena berbunga dan memiliki percabangan yang unik.

\subsubsection{Area Terapi dan Area Duduk}

Area ini paling banyak dikunjungi sepanjang hari. Hal ini dikarenakan, area ini paling banyak memfasilitasi bangku taman. Area terapi lebih banyak didominasi dengan semak dan penutup tanah dengan 
jalur terapi sedangkan area duduk didominasi oleh perkerasan dengan banyak pohon peneduh. Fungsi vegetasi di area terapi adalah sebagai estetika karena semak seperti Korimbosa, Sambang Colok, Sambang Darah, Spider Lily, Aralia, Teh-tehan, dan Pangkas Kuning serta palem yang digunakan ditata dengan baik dan dipilih vegetasi dengan daun dan bunga yang indah. Kemudian Cemara Cina ditanam sebagai pembatas antara jalur joging dengan lapangan. Area duduk memiliki tanaman peneduh yang banyak dan didominasi oleh pohon Tanjung. Tanjung memiliki tajuk lebar dan bermassa daun padat sehingga area duduk ternaungi sepenuhnya. Pohon peneduh lainnya yaitu Ketapang dan Cempaka.

\subsubsection{Lapangan}

Lapangan berada tepat di bagian tengah Lapangan Puputan Badung I Gusti Ngurah Made Agung. Lapangan juga merupakan area terluas dari tapak ini. Berbagai macam aktivitas dapat dilakukan di area ini karena luas dan terbuka. Beberapa jenis aktivitas disini yaitu bermain olahraga, bersantai, dan yoga serta beberapa kegiatan berskala besar seperti Denpasar Festival yang diadakan setahun sekali.

Rumput-rumputan sangat mendominasi area ini. Menurut $C A B$ International (2018), kedua jenis penutup tanah yaitu Rumput Paetan dan Rumput Belulang merupakan vegetasi yang tumbuh dengan cepat jika memperoleh sinar matahari penuh serta air yang cukup. Rumput Paetan dan Rumput Belulang berkembang biak dengan menggunakan biji yang dapat diterbangkan oleh angin atau terbawa oleh serangga yang hinggap. Pemilihan kedua rumput ini sebagai penutup tanah di lapangan dengan intensitas pemakaian yang cukup tinggi setiap harinya sudah sesuai. Hal ini dapat meminimalisasi perawatan karena kedua jenis rumput ini dapat dengan mudah mengalami revitalisasi tanpa perawatan intensif. Selain itu, kedua rumput ini tidak memiliki bahaya seperti racun ataupun duri sehingga lapangan amat dijadikan tempat bermain untuk anak maupun balita.

\section{Simpulan}

Lapangan Puputan Badung I Gusti Ngurah Made Agung memiliki delapan jenis penutup tanah, 31 jenis semak, dan 25 jenis pohon. Hasil penilaian setiap jenis vegetasi tersebut menghasilkan rentangan nilai kesesuaian mulai dari cukup sesuai hingga sesuai. Ruang aktivitas di Lapangan Puputan Badung I Gusti Ngurah Made Agung sangat beragam diantaranya jalur joging, area monumen, area bermain anak, area gym, panggung, area terapi dan duduk serta lapangan. Peletakan vegetasi di ruang-ruang aktivitas sudah sesuai dan memiliki fungsi meliputi fungsi peneduh, pengarah, estetika, dan pembatas. Fungsi vegetasi tersebut juga mempengaruhi aktivitas dan waktu penggunaan ruang-ruang aktivitas.

\section{Daftar Pustaka}

Balai Perbenihan Tanaman Hutan Sulawesi. 2012. Daftar Seed Leaflet. Tersedia online pada: https://sipth.simpdashl.menlhk.go.id/ (Diakses pada November 2018)

BMKG (Badan Meteorologi, Klimatologi dan Geofisika). 2018. Data Iklim Stasiun Sanglah, Denpasar. Badung: BMKG Wilayah III Denpasar.

CAB International. 2018. Invansive Species Compendium. Online at: https://cabi.org/ (Accessed Desember 2018).

DPU (Departemen Pekerjaan Umum). 2008. Peraturan Menteri Pekerjaan Umum Nomor: 05/PRT/M/2008 tentang Pedoman Penyediaan dan Pemanfaatan Ruang Terbuka Hljau di Kawasan Perkotaan.

DPU (Departemen Pekerjaan Umum). 2012. Peraturan Menteri Pekerjaan Umum Nomor: 05/PRT/M/2012 tentang Pedoman Penanaman Pohon pada Sistem Jaringan Jalan.

Min, B.C., S. Y. J. Chew, J. W. H. Yong. 2014. Plants in Tropical Cities. Singapore: Uvaria Tide.

Mukhlison. 2013. Pemilihan Jenis Pohon untuk Pengembangan Hutan Kota di Kawasan Perkotaan Yogyakarta. Jurnal IImu Kehutanan, VII(1):37-47.

National Parks Singapore. 2013. Plants. Available online at: https://florafaunaweb.nparks.gov.sg/ (Accessed September 2018).

Urban Forest Ecosystems Institute. 2018. SelectTree. Available online at: https://selectree.calpoly.edu/ (Accessed September 2018). 